\title{
Woodsholea maritima gen. nov., sp. nov., a marine bacterium with a low diversity of polar lipids
}

\section{Correspondence Wolf-Rainer Abraham wab@gbf.de}

\author{
Wolf-Rainer Abraham, ${ }^{1}$ Carsten Strömpl, ${ }^{1}$ Marc Vancanneyt, ${ }^{2}$ \\ Antonio Bennasar, ${ }^{3}$ Jean Swings, ${ }^{2}$ Heinrich Lünsdorf, ${ }^{1}$ John Smit ${ }^{4}$ \\ and Edward R. B. Moore ${ }^{5}$ \\ ${ }^{1}$ GBF - German Research Centre for Biotechnology, Mascheroder Weg 1, D-38124 \\ Braunschweig, Germany \\ ${ }^{2}$ BCCM/LMG Bacteria Collection, Universiteit Gent, K.L. Ledeganckstraat 35, B-9000 Gent, \\ Belgium \\ ${ }^{3}$ Area de Microbiologia, Campus UIB - Edifici Guillem Colom, Universitat de les Illes Balears, \\ Crta. Valldemossa km 7·5, 07122 Palma de Mallorca, Spain \\ ${ }^{4}$ Dept of Microbiology and Immunology, University of British Columbia, Vancouver, British \\ Columbia, Canada \\ ${ }^{5}$ The Macaulay Research Institute, Craigiebuckler, Aberdeen AB15 80H, UK
}

Two cauliform bacteria $\left(\mathrm{CM} 243^{\top}\right.$ and CM251) isolated by J. Poindexter from the Atlantic Ocean were characterized by $16 \mathrm{~S}$ rRNA gene sequencing, Taql restriction fragment length polymorphism and single-strand conformation polymorphism analyses of the internally transcribed 16S-23S rDNA spacer (ITS1) region, analysis of fatty acids from cellular lipids, mass spectrometry of polar lipids and physiological properties. The two strains showed very low diversity of polar lipids with diacyl-sulfoquinovosyl glycerols as the predominant lipids. The two bacterial strains were observed to have nearly identical 16S rRNA gene sequences and could not be differentiated by their ITS1 regions. The isolates differed from species of the genus Maricaulis by their $16 \mathrm{~S}$ rRNA gene sequences, polar lipids and fatty acid patterns. On the basis of the genotypic analyses and estimations of phylogenetic similarities, physiological and chemotaxonomic characteristics, it is proposed that the isolates represent a new genus and species, for which the name Woodsholea maritima gen. nov., sp. nov. (type strain $\mathrm{CM} 243^{\top}=$ VKM B $-1512^{\top}=$ LMG $21817^{\top}$ ) is proposed.
Aquatic habitats, especially the oceans, are still a rich source for unusual bacteria and Jean Poindexter and others isolated a number of marine bacteria that were grouped into the genus Caulobacter by their characteristic cell morphology (Poindexter, 1964, 1981b). These bacteria were observed to have dimorphic, prosthecate cells in which reproduction takes place by the separation of two cells that are morphologically and behaviourally different from each other. One cell is sessile, fixed by adhesive material to the substrata

Published online ahead of print on 9 February 2004 as DOI 10.1099/ ijs.0.02943-0.

Abbreviations: CID, collision-induced dissociation; ECL, equivalent chain-length; ESI-MS, electrospray ionization mass spectrometry; ITS1, internally transcribed spacer region; SSCP, single-strand conformation polymorphism.

The GenBank/EMBL/DDBJ accession numbers for the 16S rDNA sequences of strains $\mathrm{CM}_{24}{ }^{\top}$ and $\mathrm{CM} 251$ are AJ578476 and AJ578477, respectively. and possessing one elongated cylindrical appendage - a prostheca (Staley, 1968). The other cell is motile by a single polar flagellum. The mode of reproduction of the dimorphic prosthecate bacteria helps disperse the population at each generation, thereby minimizing competition for resources. It is consistent with their life style that these bacteria possess tolerance of prolonged nutrient scarcity (Poindexter, 1981a).

Caulobacteria are ubiquitous in aquatic and marine ecosystems and are presumed to be responsible for considerable mineralization of dissolved organic material in aquatic environments, where nutrient concentrations and ambient temperatures are low (Staley et al., 1987). It is consistent with this presumption that practically any type of sea water contains caulobacteria (Jannasch \& Jones, 1960; Anast \& Smit, 1988).

The ubiquity of this type of bacteria led to their discovery more than a century ago, where the first isolation of a 
Caulobacter sp. was reported by Loeffler (1890). In 1935, the genus Caulobacter was described (Henrici \& Johnson, 1935) and, three decades later, Jean Poindexter isolated a large number of caulobacteria from different habitats and described nine species (Poindexter, 1964).

Anast \& Smit (1988) were the first to recognize differences between freshwater and marine caulobacteria in a large set of strains. The comparison of $16 \mathrm{~S}$ rRNA gene sequences of several isolates belonging to Caulobacter revealed that the isolates actually form two different lineages (Stahl et al., 1992). A study of the diversity of more than 100 different freshwater and marine Caulobacter strains including lipid analysis, immunological profiling, $16 \mathrm{~S}$ rRNA gene sequencing and physiological data led to the reclassification of many Caulobacter species as Brevundimonas species and the proposal of the new genus Maricaulis (Abraham et al., 1999). In this study, marine isolates were identified as belonging to this new genus, and four additional species of Maricaulis have since been proposed (Abraham et al., 2002). However, some of the marine strains isolated by Poindexter and others did not fit into the genus Maricaulis or into the newly described genus Oceanicaulis (Strömpl et al., 2003), and the aim of this communication is to describe two of them and to place them into a new genus.

The strains of this study and the origin of the isolates are listed in Table 1. All strains were grown in marineCaulobacter medium SPYEM: $30 \mathrm{~g}$ sea salts (Sigma), $0.5 \mathrm{~g}$ $\mathrm{NH}_{4} \mathrm{Cl}, 11$ Milli-Q water. After autoclaving and cooling, $20 \mathrm{ml} 50 \times$ PYE (100 g peptone and $50 \mathrm{~g}$ yeast extract in 1 ldeionized water, autoclaved), $2 \mathrm{ml} 50 \%$ glucose (sterile) and $5 \mathrm{ml}$ filter-sterilized riboflavin $\left(0 \cdot 2 \mathrm{mg} \mathrm{ml}^{-1}\right)$ were added. The strains were incubated in 21 flasks at $30{ }^{\circ} \mathrm{C}$ and 100 r.p.m. and the biomass was harvested in the late exponential phase after $72 \mathrm{~h}$.
Genomic DNA isolation, determination of DNA base composition, PCR amplification of nearly complete $16 \mathrm{~S}$ rRNA genes, subsequent sequencing of the amplicons and the mode of analysis have been described elsewhere (Abraham et al., 2002). Resulting sequences were aligned and phylogenetic trees were constructed in the ARB program (http://www.arb-home.de). For analysis of the 16S$23 \mathrm{~S}$ rDNA interspacer region (ITS1), two PCR primers were used: $16 \mathrm{f} 945$, corresponding to positions 927 to 945 of the Escherichia coli 16S rDNA (Brosius et al., 1978), and $23 r 458$, corresponding to positions 458 to 473 of the E. coli $23 \mathrm{~S}$ rDNA (Brosius et al., 1980). Fingerprint analysis of the ITS1 PCR products after digestion with TaqI and singlestrand conformation polymorphism (SSCP) analysis (Orita et al., 1989) of the resulting restriction fragments were performed as described elsewhere (Abraham et al., 2002).

After an incubation period of $48 \mathrm{~h}$ on SPYEM agar plates at $28{ }^{\circ} \mathrm{C}$, a loopful of biomass was harvested for wholecell fatty acid analysis and fatty acid methyl esters were prepared as described previously (Abraham et al., 2002). Fatty acid methyl esters were separated and identified using the Microbial Identification System (MIDI). Lipids were extracted using a modified Bligh-Dyer procedure (Bligh \& Dyer, 1959) as described previously (Vancanneyt et al., 1996). This total lipid fraction was fractionated by column chromatography and the phospholipid fraction was analysed by electrospray ionization mass spectrometry (ESIMS). ESI-MS in the negative mode was performed in a QTOF-MS. Neon served as the collision gas for high-energy collision-induced dissociation (CID). ${ }^{1} \mathrm{H}$ NMR spectra were recorded in $7: 3 \mathrm{~d}$-chloroform $/ \mathrm{d}_{3}$-methanol at $300 \mathrm{~K}$ on a Bruker ARX-400 NMR spectrometer relative to internal tetramethylsilane.

Strains were grown with different concentrations of $\mathrm{NaCl}$

Table 1. Strains used in this study

Abbreviations: LMG, BCCM/LMG Bacteria Collection, Universiteit Gent, Belgium; ATCC, American Type Culture Collection, Manassas, VA, USA; DSM, Deutsche Sammlung für Mikroorganismen und Zellkulturen, Braunschweig, Germany; VKM, All-Russian Collection of Microorganisms of the Academy of Sciences, Institute of Biochemistry and Physiology of Microorganisms, Russian Academy of Sciences, Pushchino, Russia.

\begin{tabular}{|ll|}
\hline Strain & \\
\hline $\mathrm{CM} 243^{\mathrm{T}}\left(=\mathrm{VKM} \mathrm{B}-1512^{\mathrm{T}}=\mathrm{LMG} 21817^{\mathrm{T}}\right)$ & Origin \\
$\mathrm{CM} 251(=\mathrm{LMG} 21818)$ & Estuarine water, Woods Hole, MA, USA, J. Poindexter \\
Maricaulis maris ATCC $15268^{\mathrm{T}}$ & Estuarine water, Woods Hole, MA, USA, J. Poindexter \\
Maricaulis parjimensis MCS $25^{\mathrm{T}}\left(=\mathrm{LMG} 19863^{\mathrm{T}}\right)$ & Filtered sea water \\
Maricaulis salignorans MCS $18^{\mathrm{T}}\left(=\mathrm{LMG} 19864^{\mathrm{T}}\right)$ & Filtered sea water, Indian Ocean off Goa, India \\
& Sea water, Salsbury Point County Park, adjacent to Hood \\
Maricaulis virginensis $\mathrm{VC}-5^{\mathrm{T}}\left(=\mathrm{VKM} \mathrm{B}-1513^{\mathrm{T}}\right)$ & Canal, Bridge, WA, USA \\
Maricaulis washingtonensis $\mathrm{MCS} 6^{\mathrm{T}}\left(=\mathrm{LMG} 19865^{\mathrm{T}}\right)$ & Deep-sea, Virgin Islands, J. Poindexter \\
Oceanicaulis alexandrii C116-18 & Sea water, Inner marina, Edmonds, WA, USA \\
Hyphomonas jannaschiana ATCC $33883^{\mathrm{T}}$ & Marine dinoflagellate \\
Hyphomonas polymorpha DSM $2665^{\mathrm{T}}$ & Mussel bed in Galapagos thermal vent \\
& Human nasal sinus infection \\
\hline
\end{tabular}



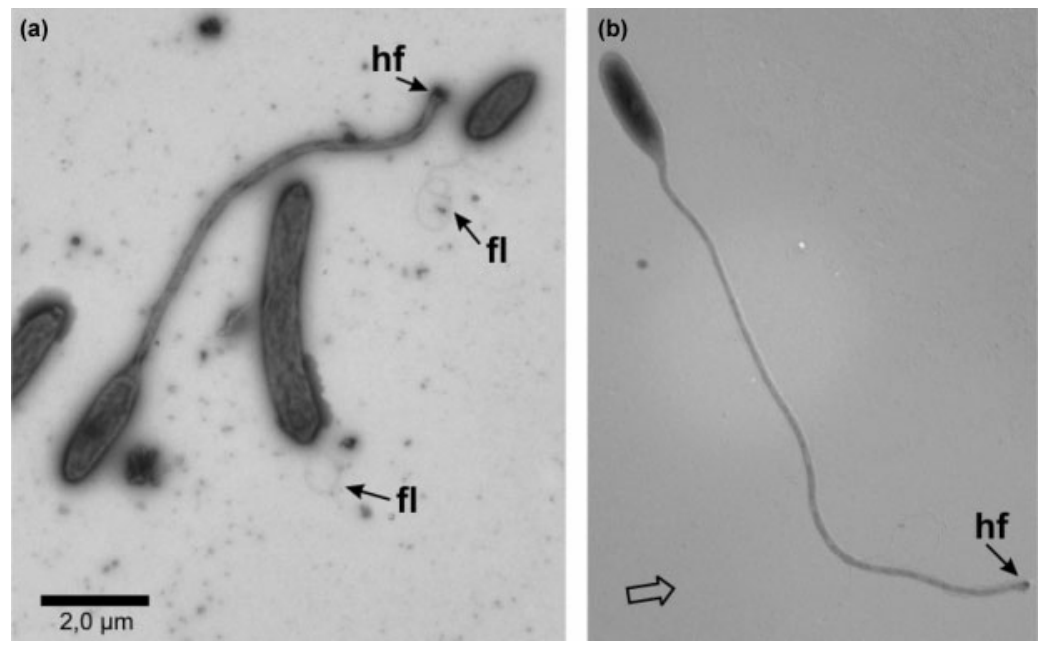

Fig. 1. Cells of the marine isolate $C M 243^{\top}$, growing exponentially, are depicted as negatively stained (a) and $\mathrm{Pt}$ shadow-cast (b) preparations. Typical stalks, terminated by a holdfast (hf), can be recognized. Motile swarming cells of different length are characterized by a monotrichous, monopolar flagellum (fl). Open arrow in (b) indicates the direction of shadow-cast.

and at different temperatures, for phenotypic characterizations, as described elsewhere (Abraham et al., 1999). Enzyme activity tests were conducted with the use of API ZYM test strips (bioMérieux), according to the protocol supplied by the manufacturer. Substrate specificity tests were conducted with the use of API 20NE test strips (bioMérieux) using a protocol supplied by the manufacturer. The test strips were incubated at $30^{\circ} \mathrm{C}$ for 7 days and monitored after 1,2 and 7 days. A test was considered positive when the interface between sample well and air was visibly turbid due to bacterial growth after a 7 day incubation period.

Morphology and ultrastructure of mid-exponentially growing cells of $\mathrm{CM} 243^{\mathrm{T}}$ were analysed as negatively stained and shadow-cast samples with the transmission electron microscope as described previously (Golyshina et al., 2000; Yakimov et al., 1998). As seen in Fig. 1, these cells show the typical features of Caulobacter-type Gram-negative bacteria. Both morphologies can be recognized (Fig. 1). Bacteria with a characteristic stalk, ranging from $2.5 \mu \mathrm{m}$ up to more than $12 \mu \mathrm{m}$ in length, a median diameter of $135 \mathrm{~nm}$ ( $\pm 13 \mathrm{~nm} ; n=43)$, and terminated by a distinct holdfast, are often found. They are associated with planktonic motile variants (Fig. 1), which are monotrichously and monopolarly flagellated (Fig. 1a; fl). Mid-exponentially growing cells show cell lengths from $1 \cdot 51$ to $5 \cdot 4 \mu \mathrm{m}$ and a mean cell diameter of $690 \mathrm{~nm}( \pm 13 \mathrm{~nm} ; n=30)$.

Nearly complete 16S rRNA genes were amplified and sequenced using internally binding sequencing primers. Strains CM $243^{\mathrm{T}}$ and CM251 exhibited identical sequences over the $1421 \mathrm{nt}$ analysed, except for a $\mathrm{G} \rightarrow \mathrm{C}$ exchange at base position 306. Results from initial FASTA database searches indicated affiliation of the two strains with the 'Alphaproteobacteria' (Garrity et al., 2001). Detailed alignments in ARB showed that strains CM $243^{\mathrm{T}}$ and CM251 clustered within the Rhodobacteraceae and were most closely related to the genera of marine caulobacteria, Maricaulis and Oceanicaulis (Fig. 2). Estimated evolutionary distances of strain $\mathrm{CM} 243^{\mathrm{T}}$ from the type strains of closely related species and relevant taxa were: $7 \cdot 48 \%$ to Maricaulis maris, $7 \cdot 79 \%$ to Maricaulis washingtonensis, $7 \cdot 87 \%$ to Maricaulis salignorans, $6 \cdot 55 \%$ to Maricaulis parjimensis, $6 \cdot 32 \%$ to Maricaulis virginensis, $7 \cdot 16 \%$ to Oceanicaulis alexandrii, $10.58 \%$ to Hyphomonas polymorpha, $11.60 \%$ to Hirschia baltica and $13.76 \%$ to Caulobacter vibrioides.

Application of neighbour-joining and parsimony methods resulted in identical tree topologies. Diagnostic sequence stretches serving to distinguish strain $\mathrm{CM} 243^{\mathrm{T}}$ from all currently recognized species of Maricaulis and Oceanicaulis can be found, for example, in helices 9, 19, 25 and 45 (Neefs et al., 1991) (data not shown). Identification of distinguishing sequence patterns, together with the evolutionary distances estimated from sequence similarity values, and the dendrogram topologies, suggest that strains $\mathrm{CM} 243^{\mathrm{T}}$ and CM251 are equally distant from Maricaulis and Oceanicaulis.

Molecular typing analysis of the 16S-23S rDNA ITS1 has been applied as a rapid bacterial identification tool for strains $\mathrm{CM} 243^{\mathrm{T}}$ and $\mathrm{CM} 251$ in order to confirm the close relationship between the strains. The use of the ITS1 region has allowed discrimination at, approximately, the species level, with correlation to DNA-DNA relatedness data (Guasp et al., 2000). For both strains, equivalent single, $1.6 \mathrm{~kb}$ ITS1 PCR products were obtained (data not shown). These PCR fragments contained approximately $0.6 \mathrm{~kb}$ of the $5^{\prime}$-region of the $16 \mathrm{~S} \mathrm{rDNA}$ and nearby $0.5 \mathrm{~kb}$ of the $3^{\prime}$-region of the $23 \mathrm{~S} \mathrm{rDNA}$, with $0.5 \mathrm{~kb}$ corresponding to the ITS1 region. TaqI restriction fingerprints obtained from the PCR products of CM243 ${ }^{\mathrm{T}}$ and CM251 were identical, consisting of six bands of between 155 and 396 bp. Furthermore, no differences between the strains were detected in the resulting single-strand profiles analysed by SSCP. Consequently, significant sequence heterogeneities that would result in different conformations and, consequently, differences in the mobilities of single strands were assumed to be absent. These results confirmed 


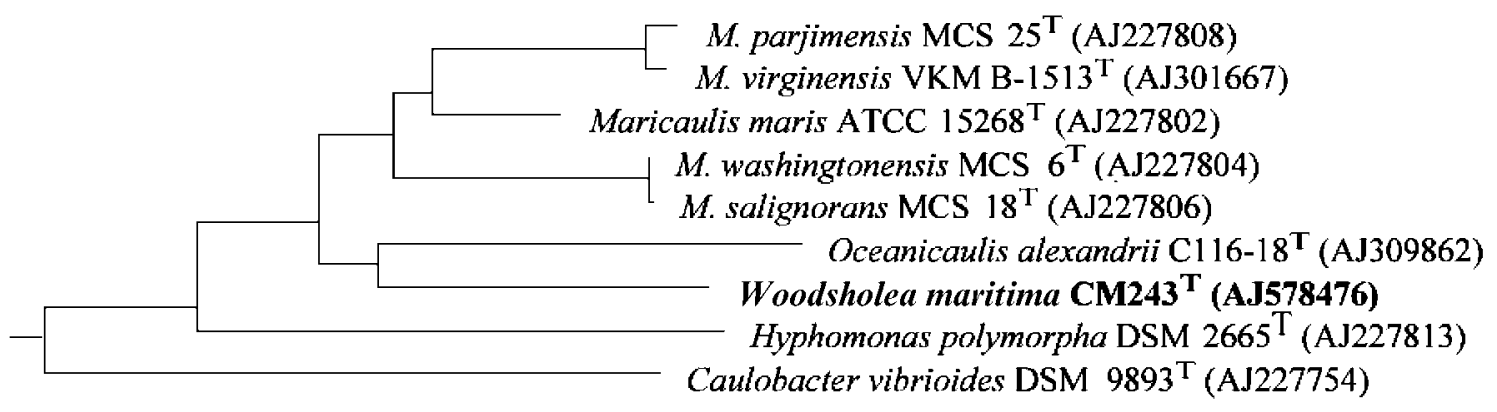

0.01

Fig. 2. Unrooted dendrogram of phylogenetic relationships with strain $C M 243^{\top}$, based on comparisons of $16 S$ rDNA sequences of the type strains of all species of the genera Maricaulis and Oceanicaulis, as well as the type strains of the type species of Hyphomonas and Caulobacter. The 16S rDNA sequences of different bacterial species, within and without the alphaproteobacteria, were used as outgroup. Strain numbers and database accession numbers of all sequences used for calculation of the distance matrix are listed. A distance matrix was calculated from only unambiguously determined, homologous positions, using DNADIST (Jukes-Cantor corrections; Jukes \& Cantor, 1969) and dendrograms of estimated phylogenetic relationships were calculated, using the FITCH program of the PHYLIP package (Felsenstein, 1989) as implemented in the ARB program (Ludwig et al., 2003). Bar, 1 nt substitution per 100 bases.

unequivocally a close phylogenetic association between the two strains.

The mass spectra of the polar lipids of strains $\mathrm{CM} 243^{\mathrm{T}}$ and CM251 showed surprisingly few peaks. The spectrum of strain CM $243^{\mathrm{T}}$ was dominated by two peaks at $\mathrm{m} / z 797$ and 847, with two minor peaks at 795 and 845 . A fifth peak was detected at $\mathrm{m} / z 904$ (Fig. 3). With the aid of CID MS, the main lipid compounds were elucidated. The ions at $\mathrm{m} / \mathrm{z}$ 795 and 797 were identified as $\alpha$-D-glucopyranosyl diacylglycerol and $\alpha$-D-glucopyranuronosyl diacylglycerols known from many other Caulobacter, Brevundimonas, Maricaulis and Hyphomonas strains (Abraham et al., 1997, 1999). The ions at $\mathrm{m} / z 845$ and 847 were identified as sulfoquinovosyl diacylglycerols and the ion at $\mathrm{m} / z 904$ as $\alpha$-D-glucuronopyranosyl diacylglycerol taurine amide also described in Maricaulis and Hyphomonas strains. The fatty acids and their position on the glycerol backbone can be determined by the more frequent loss of those fatty acids positioned at $s n-2$ as free fatty acid as well as substituted ketene (Murphy \& Harrison, 1994). With this method, the structures of the anions and hence the structure of the glyco- and sulfolipids were identified (Table 2). For the ions at $\mathrm{m} / z 795$ and 904, because of their low intensities, no CID spectra were obtained. Instead, their compositions were assumed to be similar to identical ions observed in the MS spectra of Maricaulis and Hyphomonas species (Abraham et al., 1997).

The main glycolipids in $\mathrm{CM} 243^{\mathrm{T}}$ and CM251 were also found commonly in all Maricaulis, Oceanicaulis and Hyphomonas species. The situation was different for the main polar lipids, where phosphatidylglycerol was absent in $\mathrm{CM} 243^{\mathrm{T}}$ and CM251, was found only in some species of Maricaulis and was present in all Hyphomonas and Oceanicaulis species. The occurrence of the sulfolipid

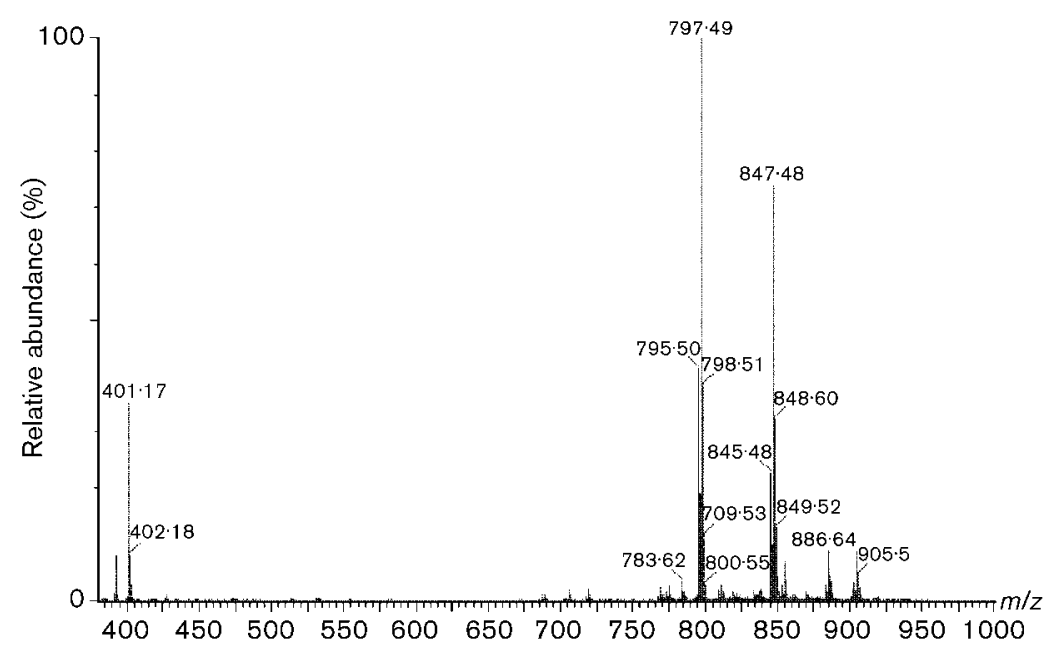

Fig. 3. ESI-MS of the polar lipid extract of strain $\mathrm{CM} 243^{\top}$. The prominent peaks at $\mathrm{m} / \mathrm{z}$ 795 and 797 are glucopyranosyl- and glucopyranuronosylglycerol glycolipids and those at $\mathrm{m} / \mathrm{z} 845$ and 847 are sulfoquinovosyl lipids. A small peak at $\mathrm{m} / \mathrm{z} 903$ suggests a glucuronopyranosyl-sn-glycerol taurineamide. 
Table 2. Polar lipids identified in Woodsholea maritima $\mathrm{CM} 243^{\top}$

MGD, 1,2-di-O-acyl-3-O- $\alpha$-D-glucopyranosylglycerol; MGDOx, 1,2-di-O-acyl-3-O- $\alpha$-D-glucopyranuronosylglycerol; SQDG, 1,2diacyl-3-O-sulfoquinovosylglycerol; TAU, 1,2-diacyl-3- $\alpha$-Dglucuronopyranosyl-sn-glycerol taurineamide.

\begin{tabular}{|lllllll|}
\hline \multicolumn{3}{|c}{ Glycolipids } & & \multicolumn{3}{c|}{ Sulfolipids } \\
\cline { 1 - 3 } \cline { 5 - 7 } Mass & \multirow{2}{*}{ Type } & Fatty acids & & Mass & Type & Fatty acids \\
\hline 796 & MGDOx & $18: 1-18: 1$ & & $846^{\star}$ & SQDG & $18: 1-18: 1$ \\
$798^{\star}$ & MGD & $19: 0-18: 1$ & & $848^{\star}$ & SQDG & $18: 1-18: 0$ \\
$798^{*}$ & MGDOx & $18: 1-18: 0$ & & 904 & TAU & $18: 1-18: 0$ \\
\hline
\end{tabular}

${ }^{\star}$ Compounds analysed by CID.

1,2-diacyl-3-O-sulfoquinovosylglycerol is restricted to species of the genera Maricaulis and Oceanicaulis as well as $\mathrm{CM} 243^{\mathrm{T}}$ and CM251, while it was lacking in Hyphomonas species. Another sulfolipid, 1,2-diacyl-3- $\alpha-\mathrm{D}-$ glucuronopyranosyl-sn-glycerol taurineamide, also found in $\mathrm{CM} 243^{\mathrm{T}}$ and CM251, is known from Hyphomonas species
Table 3. Polar lipids as biomarkers in Woodsholea maritima and related genera (Abraham et al., 1999)

1,2-di-O-acyl-3-O- $\alpha$-D-glucopyranosylglycerol and 1,2-di-O-acyl-3$O-\alpha$-D-glucopyranuronosylglycerol were present in all genera. $\mathrm{PG}$, Phosphatidylglycerol; SQDG, 1,2-diacyl-3-O-sulfoquinovosylglycerol; TAU, 1,2-diacyl-3- $\alpha$-D-glucuronopyranosyl-sn-glycerol taurineamide. +++ , Present in all strains; + , present in some species; - , absent.

\begin{tabular}{|lccc|}
\hline Genus & PG & SQDG & TAU \\
\hline Woodsholea & - & +++ & +++ \\
Maricaulis & + & +++ & + \\
Oceanicaulis & +++ & +++ & - \\
Hyphomonas & +++ & - & +++ \\
\hline
\end{tabular}

but was found only in those Maricaulis strains that are closely related to M. maris (Abraham et al., 2002) (Table 3). Strains CM243 ${ }^{\mathrm{T}}$ and CM251 showed a low diversity of fatty acids and phospholipids, in marked contrast to the phylogenetically related genera Maricaulis and Hyphomonas. Such a low diversity of fatty acids was recently reported, as well, for Parvularcula bermudensis, a marine bacterium

Table 4. Fatty acid content (mean percentage of total) of whole-cell hydrolysates of Woodsholea maritima strains and those of related genera

Strains: 1, W. maritima CM243 ${ }^{\mathrm{T}}$; 2, W. maritima CM251; 3, M. parjimensis MCS $25^{\mathrm{T}} ; 4$, M. washingtonensis MCS $6^{\mathrm{T}}$; 5 , M. maris ATCC $15268^{\mathrm{T}}$; 6, M. salignorans MCS $18^{\mathrm{T}}$; 7, M. virginensis VKM B-1513 ${ }^{\mathrm{T}} ; 8$, H. polymorpha DSM $2665^{\mathrm{T}}$; 9, H. jannaschiana ATCC $33833^{\mathrm{T}}$. Those fatty acids for which the amount for all taxa was less than $1 \%$ are not given. tr, Trace amount (less than $1 \%$ ); - , not detected.

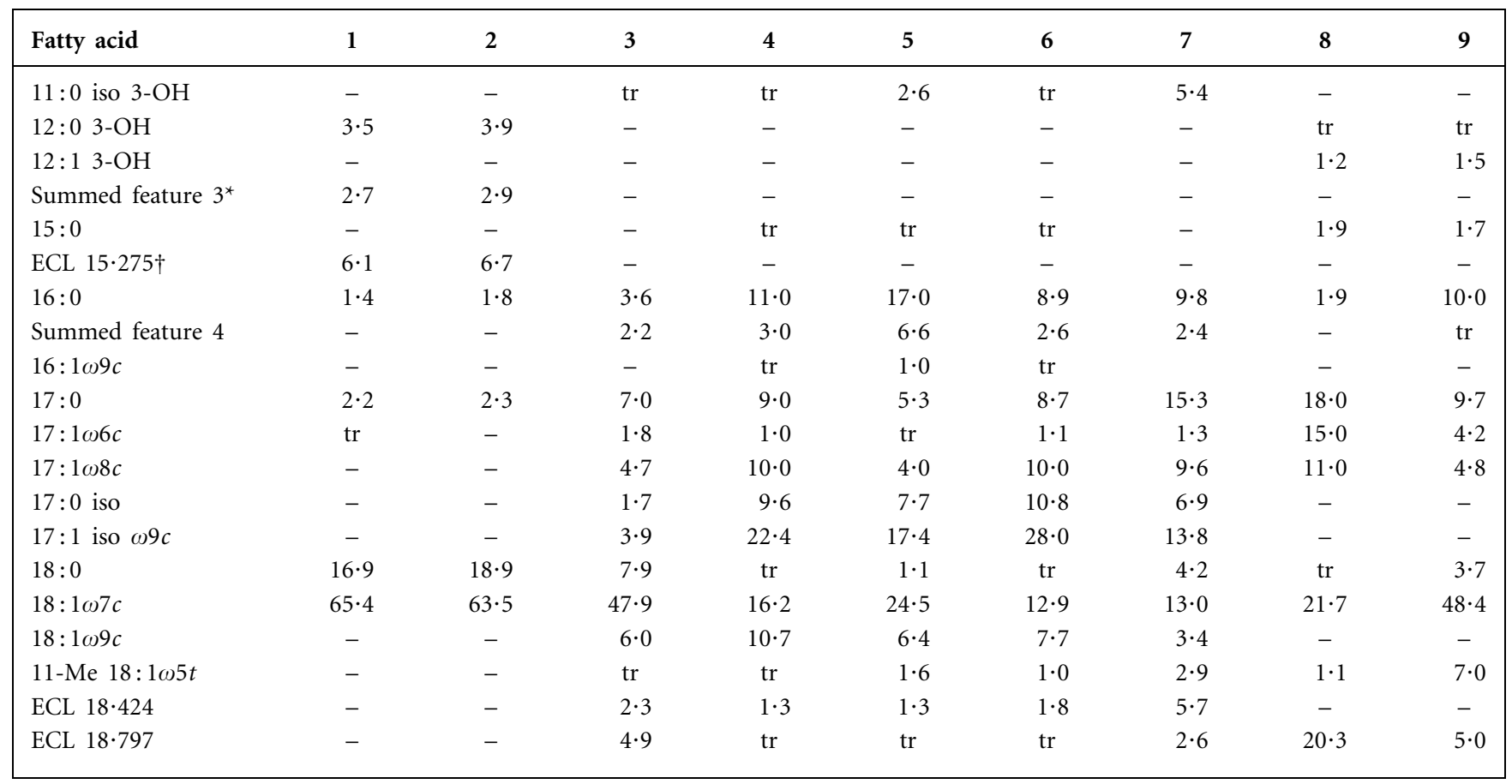

${ }^{*}$ Summed features consist of one or more fatty acids that could not be separated by the Microbial Identification System. Summed feature 3: $14: 0$ 3-OH, 16:1 iso I, ECL 10.928 and/or 12:0 ALDE. Summed feature 4: 15:0 iso 2-OH, 16:1 $1 \omega 7 c$ and/or $16: 1 \omega 7 t$.

$\dagger$ Unidentified fatty acids with equivalent chain-length (ECL) given. 
that comprises a deep phylogenetic branch in the 'Alphaproteobacteria' (Cho \& Giovannoni, 2003).

The total cellular fatty acid compositions of strains CM243 ${ }^{\mathrm{T}}$ and CM251 were determined (Table 4). The predominant fatty acids present in both strains were $12: 03-\mathrm{OH}, 16: 0$, $17: 0,18: 0$, summed feature $3,18: 1 \omega 7 c$ and the unidentified fatty acid ECL $15 \cdot 275$. Strains CM $243^{\mathrm{T}}$ and CM251 differed from Maricaulis species in their fatty acid profiles by the presence of 12:03-OH, summed feature 3 and the unidentified fatty acid ECL $15 \cdot 275$, and by the absence of $11: 0$ iso 3-OH, $17: 1 \omega 6 c, 17: 1 \omega 8 c$, iso- $17: 0$, iso- $17: 1 \omega 9 c$, $18: 1 \omega 9 c$, $11-\mathrm{Me} 18: 1 \omega 5 t$, summed feature 4 and the unidentified fatty acids ECL 18.424 and ECL 18.797 (Table 3). Hyphomonas species were observed to differ from strains $\mathrm{CM} 243^{\mathrm{T}}$ and CM251 by the absence of summed feature 3 and the unidentified fatty acid ECL $15 \cdot 275$, and by the presence of $12: 13-\mathrm{OH}, 15: 0,17: 1 \omega 6 c$, $17: 1 \omega 8 c$ and the unidentified fatty acid ECL $18 \cdot 797$ (Table 3). Poly- $\beta$-hydroxybutyrate was detected in the ${ }^{1} \mathrm{H}$ NMR spectra of total lipid extracts of CM $243^{\mathrm{T}}$ and CM251.

Strains CM243 ${ }^{\mathrm{T}}$ and CM251 were able to grow on peptone/ yeast extract media with $\mathrm{NaCl}$ concentrations between 5 and $100 \mathrm{~g} \mathrm{l}^{-1}$, showing optimal growth with $40 \mathrm{~g} \mathrm{NaCl}^{-1}$ and no growth without $\mathrm{NaCl}$ addition. In contrast to Maricaulis species, strain $\mathrm{CM} 243^{\mathrm{T}}$ was unable to reduce nitrate to nitrite (Anast \& Smit, 1988). The growth requirements and enzyme activities observed are given in detail in the species description. In Table 5, the enzymic activities of strains $\mathrm{CM} 243^{\mathrm{T}}$ and CM251 are compared with those of Maricaulis, Oceanicaulis and Hyphomonas species.

Strains $\mathrm{CM} 243^{\mathrm{T}}$ and CM251 are considerably different from all species of Maricaulis so far described and the proposal of a species in a new genus is justified.

\section{Description of Woodsholea gen. nov.}

Woodsholea (Woods.hol'e.a. N.L. fem. n. Woodsholea named in honour of the Woods Hole Oceanographic Institution, Massachusetts, USA).

Gram-negative cells, rod-shaped, vibriod. Cells possess a stalk, varying in length depending on the strain and environmental conditions, extending from one pole as a continuation of the long axis of the cell. Adhesive material is present at the distal end of the stalk. Occur singly. Multiplication by binary fission. Colonies circular, convex, colourless. Chemo-organotrophic, aerobes, cells can store carbon as poly- $\beta$-hydroxybutyric acid. Requirement for organic growth factors is complex and not satisfied by mixtures of B vitamins and amino acids. Grows on peptone/yeast extract media with $40 \mathrm{~g} \mathrm{NaCl} \mathrm{l}^{-1}$. Growth is inhibited or cells become deformed in media containing $1 \%(\mathrm{w} / \mathrm{v})$ or more organic material. Growth temperature range is $20-40{ }^{\circ} \mathrm{C}$ and optimal $\mathrm{pH}$ for growth is approximately neutral. Do not reduce nitrate, oxidize tryptophan to indole or hydrolyse arginine, urea, aesculin, gelatin or p-nitrophenyl-3-D-galactopyranoside. Do not use glucose, arabinose, mannose, mannitol, $\mathrm{N}$-acetylglucosamine, maltose, gluconate, caprate, adipate, malate, citrate or phenylacetate as carbon sources. Cells show no catalase activity, are positive for alkaline phosphatase, naphthol-ASBI-phosphohydrolase, leucine arylamidase, acid phosphatase, esterase $\left(\mathrm{C}_{4}\right)$, esterase lipase $\left(\mathrm{C}_{8}\right)$, oxidase and trypsin but negative for $\alpha$ - and $\beta$-galactosidase, $\alpha$-glucuronidase, $\alpha$-and $\beta$-glucosidase, $\alpha$-mannosidase and $\alpha$-fucosidase. The

Table 5. Enzymic assays and indicator cellular fatty acids of $\mathrm{CM}_{243^{\top}}$ and type species of related genera

Strains: 1, Maricaulis washingtonensis MCS $6^{\mathrm{T}} ; 2$, M. salignorans MCS $18^{\mathrm{T}} ; 3$, M. parjimensis MCS $25^{\mathrm{T}} ; 4$, M. maris ATCC $15268^{\mathrm{T}}$; 5 , CM243 $; 3^{\mathrm{T}}$ 6, CM251; 7, Oceanicaulis alexandrii $\mathrm{C} 116-18^{\mathrm{T}} ; 8$, Hyphomonas polymorpha DSM $2665^{\mathrm{T}}$. No activity of $\alpha$-galactosidase, $\beta$-galactosidase, $\alpha$-glucuronidase, $\alpha$-mannosidase or $\alpha$-fucosidase was found in any of the species.

\begin{tabular}{|c|c|c|c|c|c|c|c|c|}
\hline Enzyme assay & 1 & 2 & 3 & 4 & 5 & 6 & 7 & 8 \\
\hline Alkaline phosphatase & ++++ & ++++ & +++++ & +++++ & +++++ & +++++ & +++++ & +++++ \\
\hline Esterase (C4) & ++++ & ++++ & +++ & +++ & +++ & ++ & ++++ & ++++ \\
\hline Lipase (C14) & + & + & + & + & + & - & + & - \\
\hline Leucine arylamidase & +++++ & +++++ & ++++ & +++++ & ++++ & +++++ & +++++ & +++ \\
\hline Trypsin & ++++ & +++++ & +++++ & ++ & +++ & ++++ & +++++ & - \\
\hline$\alpha$-Chymotrypsin & +++++ & +++++ & ++ & +++++ & ++ & - & ++++ & - \\
\hline Acid phosphatase & - & + & +++++ & - & ++++ & ++ & + & ++++ \\
\hline Naphthol-AS-BI-phosphohydrolase & ++ & ++ & ++++ & +++ & ++++ & ++ & ++ & ++ \\
\hline$\alpha$-Glucosidase & - & - & ++ & - & - & - & - & + \\
\hline
\end{tabular}


genus is characterized by two major fatty acids, $18: 0$ and $18: 1 \omega 7 c$, and minor amounts of $12: 03-\mathrm{OH}, 16: 0,17: 0$, summed feature 3 and the unidentified fatty acid ECL $15 \cdot 275$. Polar lipids are $\alpha$-D-glucopyranosyl diacylglycerol, $\alpha$-D-glucopyranuronosyl diacylglycerol, sulfoquinovosyl diacylglycerol and $\alpha$-D-glucuronopyranosyl diacylglycerol taurine amide. Isolated from sea water. The $\mathrm{G}+\mathrm{C}$ content is $65 \mathrm{~mol} \%$. The type species is Woodsholea maritima.

\section{Description of Woodsholea maritima sp. nov.}

Woodsholea maritima (L. fem. adj. maritima marine).

The description is as that of the genus with the following additions. Cells are $1.5-5.4 \times 0.7 \mu \mathrm{m}$ with a 2.5 $12 \times 0 \cdot 14 \mu \mathrm{m}$ stalk; optimal growth occurs between 5 and $100 \mathrm{~g} \mathrm{NaCl} \mathrm{l}^{-1}$. No growth without salt. Optimal growth temperature is $20-40{ }^{\circ} \mathrm{C}$; some growth is observed at $10^{\circ} \mathrm{C}$. $\mathrm{pH}$ range for growth is $6 \cdot 0-8 \cdot 0$. Main polar lipids are 1-nonadecanoyl-2-octadecenoyl-3-O- $\alpha$-D-glucopyranosylglycerol, 1-octadecenoyl-2-octadecanoyl-3-O- $\alpha$-D-glucopyranuronosylglycerol and 1,2-di-octadecenoyl-3-Osulfoquinovosylglycerol. Strains have no to weak $\alpha$-chymotrypsin and $N$-acetyl- $\beta$-glucosaminidase activities; some isolates including the type strain have very weak lipase activity. Isolates have been obtained from sea water at Woodshole, USA. The $\mathrm{G}+\mathrm{C}$ content of the type strain is $65 \cdot 2 \mathrm{~mol} \%$.

The type strain is $\mathrm{CM}_{243^{\mathrm{T}}}\left(=\mathrm{VKM} \quad \mathrm{B}-1512^{\mathrm{T}}=\mathrm{LMG}\right.$ $21817^{\mathrm{T}}$ ); a further strain is CM251 (=LMG 21818).

\section{Acknowledgements}

We thank D. Wenderoth, T. Jeschke, A. Krüger and P. Wolff for their excellent technical assistance and E. Surges for recording the mass spectra. This work was supported by grants of the German Federal Ministry for Science, Education and Research (Project no. 0319433C) and the European Union within the T-project 'High Resolution Automated Microbial Identification and Application to Biotechnologically Relevant Ecosystems'.

\section{References}

Abraham, W.-R., Meyer, H., Lindholst, S., Vancanneyt, M. \& Smit, J. (1997). Phospho- and sulfolipids as biomarkers of Caulobacter, Brevundimonas and Hyphomonas. Syst Appl Microbiol 20, 522-539.

Abraham, W.-R., Strömpl, C., Meyer, H. \& 8 other authors (1999). Phylogeny and polyphasic taxonomy of Caulobacter species. Proposal of Maricaulis gen. nov. with Maricaulis maris (Poindexter) comb. nov. as the type species, and emended description of the genera Brevundimonas and Caulobacter. Int J Syst Bacteriol 49, 1053-1073.

Abraham, W.-R., Strömpl, C., Bennasar, A., Vancanneyt, M., Snauwaert, C., Swings, J., Smit, J. \& Moore, E. R. B. (2002). Phylogeny of Maricaulis Abraham et al. 1999 and proposal of Maricaulis virginensis sp. nov., $M$. parjimensis sp. nov., $M$. washingtonensis sp. nov. and $M$. salignorans sp. nov. Int $J$ Syst Evol Microbiol 52, 2191-2201.

Anast, N. \& Smit, J. (1988). Isolation and characterization of marine caulobacters and assessment of their potential for generic experimentation. Appl Environ Microbiol 54, 809-817.
Bligh, E. G. \& Dyer, W. J. (1959). A rapid method of total lipid extraction and purification. Can J Med Sci 37, 911-917.

Brosius, J., Palmer, M. L., Kennedy, P. J. \& Noller, H. F. (1978). Complete nucleotide sequence of a $16 \mathrm{~S}$ ribosomal RNA gene from Escherichia coli. Proc Natl Acad Sci U S A 75, 4801-4805.

Brosius, J., Dull, T. J. \& Noller, H. F. (1980). Complete nucleotide sequence of a $23 \mathrm{~S}$ ribosomal RNA gene from Escherichia coli. Proc Natl Acad Sci U S A 77, 201-204.

Cho, J.-C. \& Giovannoni, S. J. (2003). Parvularcula bermudensis gen. nov., sp. nov., a marine bacterium that forms a deep branch in the $\alpha$-Proteobacteria. Int J Syst Evol Microbiol 53, 1031-1036.

Felsenstein, J. (1989). PHYLIP-phylogeny inference package (version 3.2). Cladistics 5, 164-166.

Garrity, G. M., Winters, M. \& Searls, D. B. (2001). Taxonomic outline of the procaryotic genera. In Bergey's Manual of Systematic Bacteriology, 2nd edn. Release 1.0, April 2001. Edited by G. M. Garrity, D. R. Boone \& R. W. Castenholz. New York: Springer.

Golyshina, O. V., Pivovarova, T. A., Karavaiko, G. I. \& 7 other authors (2000). Ferroplasma acidiphilum gen. nov., sp. nov., an acidophilic, autotrophic, ferrous iron-oxidizing, cell-wall-lacking, mesophilic member of Ferroplasmaceae fam. nov., comprising a distinct lineage of Archaea. Int J Syst Evol Microbiol 50, 997-1006.

Guasp, C., Moore, E. R. B., Lalucat, J. \& Bennasar, A. (2000). Utility of internally transcribed $16 \mathrm{~S}-23 \mathrm{~S}$ rDNA spacer regions for the definition of Pseudomonas stutzeri genomovars and other Pseudomonas species. Int J Syst Evol Microbiol 50, 1629-1639.

Henrici, A. T. \& Johnson, D. E. (1935). Studies on fresh water bacteria. II. Stalked bacteria, a new order of schizorayceter. J Bacteriol 30, 61-93.

Jannasch, H. W. \& Jones, G. E. (1960). Caulobacter in sea water. Limnol Oceanogr 5, 432-433.

Jukes, T. H. \& Cantor, C. R. (1969). Evolution of protein molecules. In Mammalian Protein Metabolism, pp. 21-132. Edited by H. H. Munro. New York: Academic Press.

Loeffler, F. (1890). Weitere Untersuchungen über die Beizung und Färbung der Geisseln bei den Bakterien. Zentralbl Bakteriol Parasitenkd 7, 625-639 (in German).

Ludwig, W., Strunk, O., Westram, R. \& 28 other authors (2003). ARB: a software environment for sequence data. Nucleic Acids Res 32, 1363-1371.

Murphy, R. C. \& Harrison, K. A. (1994). Fast atom bombardment mass spectrometry of phospholipids. Mass Spectrom Rev 13, $57-75$.

Neefs, J.-M., Van der Peer, V. Y., De Rijk, P., Goris, A. \& De Wachter, R. (1991). Compilation of small ribosomal subunit RNA sequences. Nucleic Acids Res 19, S1987-S2015.

Orita, M., Suzuki, Y., Sekiya, T. \& Hayashi, K. (1989). Rapid and sensitive detection of point mutations and DNA polymorphisms using the polymerase chain reaction. Genomics 5, 874-879.

Poindexter, J. S. (1964). Biological properties and classification of the Caulobacter group. Bacteriol Rev 28, 231-295.

Poindexter, J. S. (1981a). Oligotrophy. Fast and famine existence. In Microbial Ecology, vol. 5, pp. 63-89. Edited by M. Alexander. New York: Plenum.

Poindexter, J. S. (1981b). The caulobacters: ubiquitous unusual bacteria. Microbiol Rev 45, 123-179.

Stahl, D. A., Key, R., Flesher, B. \& Smit, J. (1992). The phylogeny of marine and freshwater caulobacters reflects their habitat. $J$ Bacteriol 174, 2193-2198.

Staley, J. T. (1968). Prosthecomicrobium and Ancalomicrobium: new prosthecate freshwater bacteria. J Bacteriol 95, 1921-1942. 
Staley, J. T., Konopka, A. E. \& Dalmasso, J. P. (1987). Spatial and temporal distribution of Caulobacter spp. in two mesotrophic lakes. FEMS Microbiol Ecol 45, 1-6.

Strömpl, C., Hold, G. L., Lünsdorf, H., Graham, J., Gallacher, S., Abraham, W.-R., Moore, E. R. B. \& Timmis, K. N. (2003). Oceanicaulis alexandrii gen. nov., sp. nov., a novel stalked bacterium isolated from a culture of the dinoflagellate Alexandrium tamarense (Lebour) Balech. Int J Syst Evol Microbiol 53, 1901-1906.
Vancanneyt, M., Witt, S., Abraham, W.-R., Kersters, K. \& Frederickson, H. L. (1996). Fatty acid content in whole-cell hydrolysates and phospholipid fractions of pseudomonads: a taxonomic evaluation. Syst Appl Microbiol 19, 528-540.

Yakimov, M. M., Golyshin, P. N., Lang, S., Moore, E. R. B., Abraham, W.-R., Lünsdorf, H. \& Timmis, K. N. (1998). Alcanivorax borkumensis gen. nov., sp. nov., a new hydrocarbon-degrading and surfactantproducing marine bacterium. Int J Syst Bacteriol 48, 339-348. 